\title{
Neutralization of Soluble, Synaptotoxic Amyloid $\beta$ Species by Antibodies Is Epitope Specific
}

\author{
Wagner Zago, ${ }^{1}$ Manuel Buttini, ${ }^{1}$ Thomas A. Comery, ${ }^{2}$ Christopher Nishioka, ${ }^{1}$ Shyra J. Gardai, ${ }^{1}$ Peter Seubert, ${ }^{1}$ \\ Dora Games, ${ }^{1}$ Frédérique Bard, ${ }^{1}$ Dale Schenk, ${ }^{1}$ and Gene G. Kinney ${ }^{1}$ \\ ${ }^{1} J a n s s e n$ Alzheimer Immunotherapy Research \& Development, South San Francisco, California 94080, and 2Pfizer Global Research and Development, \\ Groton, Connecticut 06340
}

Several anti-amyloid $\beta(\mathrm{A} \beta)$ antibodies are under evaluation for the treatment of Alzheimer's disease (AD). Clinical studies using the $\mathrm{N}$-terminal-directed anti- $\mathrm{A} \beta$ antibody bapineuzumab have demonstrated reduced brain PET-Pittsburg-B signals, suggesting the reduction of $A \beta$ plaques, and reduced levels of total and phosphorylated tau protein in the CSF of treated AD patients. Preclinical studies using 3D6 (the murine form of bapineuzumab) have demonstrated resolution of $\mathrm{A} \beta$ plaque and vascular burdens, neuritic dystrophy, and preservation of synaptic density in the transgenic APP mouse models. In contrast, few studies have evaluated the direct interaction of this antibody with synaptotoxic soluble $\mathrm{A} \beta$ species. In the current report, we demonstrated that $3 \mathrm{D} 6$ binds to soluble, synaptotoxic assemblies of $\mathrm{A} \beta_{1-42}$ and prevents multiple downstream functional consequences in rat hippocampal neurons including changes in glutamate AMPA receptor trafficking, AD-type tau phosphorylation, and loss of dendritic spines. In vivo, we further demonstrated that 3D6 prevents synaptic loss and acutely reverses the behavioral deficit in the contextual fear conditioning task in transgenic mouse models of $\mathrm{AD}$, two endpoints thought to be linked to synaptotoxic soluble $\mathrm{A} \beta$ moieties. Importantly $\mathrm{C}$-terminal anti- $\mathrm{A} \beta$ antibodies were ineffective on these endpoints. These results, taken with prior studies, suggest that $\mathrm{N}$-terminal anti-A $\beta$ antibodies effectively interact with both soluble and insoluble forms of $A \beta$ and therefore appear particularly well suited for testing the A $\beta$ hypothesis of AD.

\section{Introduction}

An important role for amyloid $\beta$ (A $\beta)$ in Alzheimer's disease $(\mathrm{AD})$ is supported by both genetic and pathological evidence. The $\mathrm{A} \beta$ hypothesis emerged in the 1980s to reconcile a large body of literature suggestive of the involvement of $\mathrm{A} \beta$ in $\mathrm{AD}$ pathology (Hardy and Selkoe, 2002). While this hypothesis has undergone iterative modification to account for the fact that both insoluble and soluble forms of $\mathrm{A} \beta$ appear to play negative roles in the disease process, it has nonetheless served as a key underpinning for substantial drug discovery efforts focused on reducing the production, or aggregation of $A \beta$ or enhancing the clearance of this peptide. Passive and active immunizations have been tested in experimental settings as a means to enhance clearance of $A \beta$. Notably, actively immunizing AD patients with full-length $\mathrm{A} \beta$ (AN1792) resulted in mixed results regarding efficacy (Nicoll et al., 2003; Gilman et al., 2005). However, these trials were halted when $\sim 6 \%$ of the active treatment group developed signs of meningoencephalitis (Orgogozo et al., 2003), an event believed to be

\footnotetext{
Received March 29, 2011; revised Jan. 10, 2012; accepted Jan. 12, 2012.

Author contributions: W.Z., M.B., T.A.C., S.J.G., P.S., D.G., F.B., D.S., and G.G.K. designed research; W.Z., M.B., T.A.C., C.N., and S.J.G. performed research; W.Z., M.B., T.A.C., C.N., S.J.G., and G.G.K. analyzed data; W.Z., M.B., T.A.C., P.S., D.S., and G.G.K. wrote the paper.

This study was sponsored by Janssen Alzheimer Immunotherapy R\&D and Pfizer Global R\&D.

Authors W.Z., M.B., C.N., S.J.G., P.S., D.G., F.B., D.S., and G.G.K. are employees and/or shareholders of Janssen

Alzheimer Immunotherapy R\&D, and author T.A.C. is an employee and shareholder of Pfizer Global R\&D.

This article is freely available online through the J Neurosci Open Choice option.

Correspondence should be addressed to Wagner Zago, Janssen Alzheimer Immunotherapy Research \& Develop-

ment, 700 Gateway Blvd, South San Francisco, CA 94080. E-mail: wzago@janimm.com.

DOI:10.1523/JNEUROSCI.1676-11.2012

Copyright $\odot 2012$ the authors $\quad 0270-6474 / 12 / 322696-07 \$ 15.00 / 0$
}

caused by an $\mathrm{A} \beta$-directed cytotoxic T-cell response. Accordingly, new approaches were pursued that limited $\mathrm{A} \beta$-directed $\mathrm{T}$-cell involvement. Notable among these approaches are (1) active vaccines that use short $A \beta$ peptide fragments conjugated to larger protein carriers, and (2) passive immunization approaches using monoclonal antibodies (Schenk, 2002). One such antibody, bapineuzumab, is an N-terminal-directed anti- $\mathrm{A} \beta$ monoclonal antibody $(\mathrm{mAb})$ that was humanized from the murine anti- $\mathrm{A} \beta$ antibody 3D6 (Black et al., 2010; Panza et al., 2011) and is currently in Phase 3 clinical trials for the treatment of mild/moderate Alzheimer's disease. While considerable literature exists demonstrating that 3D6 prevents the formation and enhances the clearance of insoluble forms of $A \beta$ in plaque forming mice, both in the parenchyma and on cerebral vasculature (Bard et al., 2000; Schroeter et al., 2008), there are relatively few reports providing direct evidence that 3D6 also interacts with soluble $\mathrm{A} \beta$ species (Shankar et al., 2008; Spires-Jones et al., 2009; Jin et al., 2011) and uncertainty remains in the field with respect to the ability of this antibody to interact with soluble synaptotoxic forms of $\mathrm{A} \beta$ (Gandy, 2010).

Accordingly, we performed studies to evaluate the ability of 3 D6 to interact with and neutralize soluble synaptotoxic forms of the $A \beta$ peptide. To determine the epitope specificities of observed activities, we directly compared these effects with the actions of $\mathrm{A} \beta 42$-specific $\mathrm{C}$-terminal (21F12 and 16C11) and other $\mathrm{N}$-terminal (12A11)-directed mAbs. In vitro, we characterized the ability of 3D6 to interact with and inhibit the binding of soluble $\mathrm{A} \beta$ to neurons using rat hippocampal primary neuronal cultures (Lacor et al., 2004; Shughrue et al., 2010). In 
this same preparation we evaluated the ability of 3D6 to reduce physiological changes known to be caused by soluble synaptotoxic $A \beta$ such as reduction of spine density (Shughrue et al., 2010), trafficking of the AMPA subunit GluR2 (Hsieh et al., 2006; Zhao et al., 2010) and phosphorylation of tau protein (De Felice et al., 2008). Using the PDAPP mouse model we evaluated the ability of 3D6 and 21F12 to preserve synapses as measured by synaptophysin immunohistochemistry as has been previously demonstrated (Buttini et al., 2005) and further evaluated the in vivo effects of these treatment on a behavioral pharmacodynamic endpoint sensitive to soluble synaptotoxic $\mathrm{A} \beta$ [the contextual fear conditioning behavioral assay using the Tg2576 mouse model (Comery et al., 2005)].

\section{Materials and Methods}

Preparation of soluble $A \beta$ solutions. Synthetic, soluble $A \beta$ solutions were prepared using previously described methods (Lambert et al., 2001). Briefly, 1,1,1,3,3,3-hexafluoro-2-propanol (HFIP, Sigma-Aldrich Corp.) films from synthetic $\mathrm{A} \beta_{1-42}$ peptide (American Peptide) were dissolved in cold Neurobasal media without phenol red (Invitrogen) to a final concentration of $100 \mu \mathrm{m}$. Following an overnight incubation at $4^{\circ} \mathrm{C}$, the samples were centrifuged for $15 \mathrm{~min}$ at $14,000 \times \mathrm{g}$ at $4^{\circ} \mathrm{C}$ to remove insoluble material, and the supernatant was stored until use at $4^{\circ} \mathrm{C}$. Biotinylated $\mathrm{A} \beta$ solutions were prepared using the same method as above from N-terminal biotinylated $\mathrm{A} \beta_{1-42}$ peptide (American Peptide). For monomeric $A \beta$ preparations, HFIP films were dissolved in cold water and used immediately, while fibrillar $A \beta$ preparations were generated by dissolving $\mathrm{A} \beta$ peptide in PBS $(100 \mu \mathrm{M})$ followed by shaking incubation overnight at $37^{\circ} \mathrm{C}$. Due to the heterogeneity in $A \beta$ assembling states in the soluble $\mathrm{A} \beta_{1-42}$ preparation (Hepler et al., 2006), we refer to the molar concentrations of $\mathrm{A} \beta$ based on the starting $\mathrm{A} \beta_{1-42}$ peptide.

Native gel electrophoresis. Fractions were diluted in native sample buffer (Bio-Rad), loaded under native conditions onto precast $4-20 \%$ Tris$\mathrm{HCl}$ gels (Bio-Rad) and electrophoresed in native buffer (Bio-Rad) at 100 $\mathrm{V}$ for $1.5-2.5 \mathrm{~h}$ at $4^{\circ} \mathrm{C}$. Following electrophoresis, gels were or silver stained (Silver Xpress silver staining kit; Invitrogen Corporation).

Anti-A $\beta$ and control antibodies. The IgG2a monoclonal antibodies 3D6 (amino acids 1-5), 12A11 (amino acids 3-7), 21F12 (amino acids 3442), 16C11 (amino acids 33-42), and TY11-15 (murine IgG2a control) were obtained as previously described (Bard et al., 2000, 2003).

Hippocampal neuronal cultures. Hippocampal neurons were isolated from prenatal rat hippocampi (embryonic day 18) and cultured in antibiotic-free NbActiv4 media (both from BrainBits) at $37^{\circ} \mathrm{C}$ in an atmosphere of $5 \% \mathrm{CO}_{2}, 9 \% \mathrm{O}_{2}$ and on substrates coated with poly-lysine. Half of the medium was replaced every 3-4 d. The cultures resulted in a population enriched in large pyramidal neurons. Cells were used for the experiments after $21-28 \mathrm{~d}$ in vitro.

$A \beta$ Binding. For $\mathrm{A} \beta$ binding assays, hippocampal cultures were incubated live with $500 \mathrm{~nm}$ soluble $\mathrm{A} \beta$ or biotin- $\mathrm{A} \beta$ preparations for $15 \mathrm{~min}$ at $37^{\circ} \mathrm{C}$ in Neurobasal media without phenol red (Invitrogen). Soluble $\mathrm{A} \beta$ was preincubated with the mAbs $3 \mathrm{D} 6,12 \mathrm{~A} 11,21 \mathrm{~F} 12,16 \mathrm{C} 11$, or vehicle (PBS) $30 \mathrm{~min}$ at $37^{\circ} \mathrm{C}$ before addition to cultures. After a series of washes, the cells were fixed in $4 \%$ paraformaldehyde and detection of $A \beta$ performed with fluorescently tagged 3D6 (Alexa Fluor 647, Invitrogen) or polyclonal rabbit anti-A $\beta_{1-42}$ antibody (Millipore). When using biotin-conjugated $A \beta$, streptavidin-647 (Invitrogen) was applied for detection. For colocalization assays, cells were further permeabilized with $0.1 \%$ Triton X-100 and incubated with primary antibodies for $24 \mathrm{~h}$ at room temperature. These included a mouse anti-drebrin (Enzo Life Sciences), a rabbit anti-spinophilin (Millipore Corporation), a guinea-pig anti VGluT1 (Millipore Corporation), and a chicken anti-MAP2 (Abcam). After labeling, the cultures were washed in PBS and detection performed after incubation with appropriate secondary antibodies conjugated to Alexa fluorophores (Invitrogen).

Receptor internalization. For AMPA receptor internalization assays, hippocampal neurons were preincubated live with anti-GluR2 antibody (Millipore) on ice for $30 \mathrm{~min}$ and then treated with $500 \mathrm{~nm}$ soluble $\mathrm{A} \beta$ preparation or respective vehicle for $15 \mathrm{~min}$ at $37^{\circ} \mathrm{C}$ to induce receptor internalization. Soluble $\mathrm{A} \beta$ was preincubated with $3 \mathrm{D} 6,21 \mathrm{~F} 12$, or vehicle (PBS) $30 \mathrm{~min}$ at $37^{\circ} \mathrm{C}$ before addition to cultures. The remaining surfacebound antibodies were removed by using acidic stripping buffer $(0.5 \mathrm{M}$ $\mathrm{NaCl} / 0.2 \mathrm{M}$ acetic acid) on ice for $3 \mathrm{~min}$, and cells were then fixed in $4 \%$ paraformaldehyde and permeabilized with $0.1 \%$ Triton X-100. The internalized receptors were visualized after incubation with secondary antibodies conjugated to Alexa fluorophores (Invitrogen).

Tau phosphorylation. For phospho-tau (p-Tau) assays, hippocampal neurons were incubated with $1 \mu \mathrm{M}$ soluble $\mathrm{A} \beta$ preparation for $8 \mathrm{~h}$ at $37^{\circ} \mathrm{C}$. Immunostaining for $\mathrm{p}$-Tau with AT8 antibody (Thermo Scientific) was performed following the immunocytochemical procedures as described above.

Image acquisition and quantification. Digital images of fluorescently labeled cells were collected using either laser scanning confocal microscope (Leica, SPE) or Cellomics ArrayScan automated imaging system (Thermo Scientific). Typically, 3-10 optical fields per group per experiment were randomly sampled by software. Fields containing fewer than 2 neurons were discarded. Spine density was reported as the number of manually counted spines, visualized by combination of two image channels, drebrin and spinophilin, and divided by dendrite segment length (5-100 $\mu \mathrm{m}$ away from soma). Images were analyzed with MetaMorph imaging system (Molecular Devices).

Behavioral testing in the contextual fear conditioning (CFC) assay. Heterozygous male Tg2576 mice expressing human amyloid precursor protein with the Swedish mutation or littermate wild-type mice at 20 weeks of age were trained and tested in operant chambers controlled by Med-PC software (Med Associates) on 2 consecutive days in the CFC paradigm as previously described (Comery et al., 2005; Basi et al., 2010). Purified antibodies were administered parenterally by intraperitoneal injection at $30 \mathrm{mg} / \mathrm{kg}$ dissolved in PBS, $24 \mathrm{~h}$ before the training session on the first day. Freezing scores for each animal were converted to percentage freezing for each portion of the test. Memory for the context (contextual memory) for each animal was obtained by subtracting freezing score in the novel condition (a measure of basal activity) from that observed in the context.

Synaptophysin. Purified antibodies dissolved in PBS were administered parenterally by intraperitoneal injection of $3 \mathrm{mg} / \mathrm{kg}$ per week for 6 months to plaque-bearing heterozygous PDAPP mice (12-month old, females). Control PDAPP mice received equivalent injections of an isotype-matched negative control antibody (TY11-15). At the end of all treatments, mice were killed and perfused transcardially with PBS. The brains were quickly removed and fixed for $48 \mathrm{~h}$ in phosphate-buffered $4 \%$ paraformaldehyde before being processed for immunohistochemistry. Forty-micrometer free-floating sections were immunostained with anti-synaptophysin antibody (clone SY38; Dako) and FITC-labeled secondary antibody following a standard protocol. Immunolabeled brain sections were imaged with a laser scanning confocal microscope and synaptophysin levels were assessed in the frontal neocortex, as described previously (Buttini et al., 2005).

Statistical analysis. For statistical analysis, differences among groups were examined by one-way ANOVA, followed by Dunnett's post hoc test for comparison of individual group means. A criterion for statistical confidence of $p<0.05$ was adopted.

\section{Results}

Binding of the $\mathrm{N}$-terminal antibody $3 \mathrm{D} 6$ to soluble $A \boldsymbol{\beta}$ species To investigate the binding characteristics of soluble $A \beta$ species to neurons, we used a known, heterogeneous preparation of synthetic $A \beta_{1-42}$ peptide enriched in synaptotoxic oligomeric species and devoid of insoluble material (Lambert et al., 2001; Hepler et al., 2006). The presence of a heterogeneous population of high-molecular weight assemblies was confirmed by native gel analysis (Fig $1 A$; molecular weight standards used for reference only). For purposes of clarity, we refer to soluble synaptotoxic forms of $\mathrm{A} \beta$ herein as a general term to avoid any confusion surrounding the absolute size or folded/misfolded state of a relevant $\mathrm{A} \beta$ species since the current literature de- 


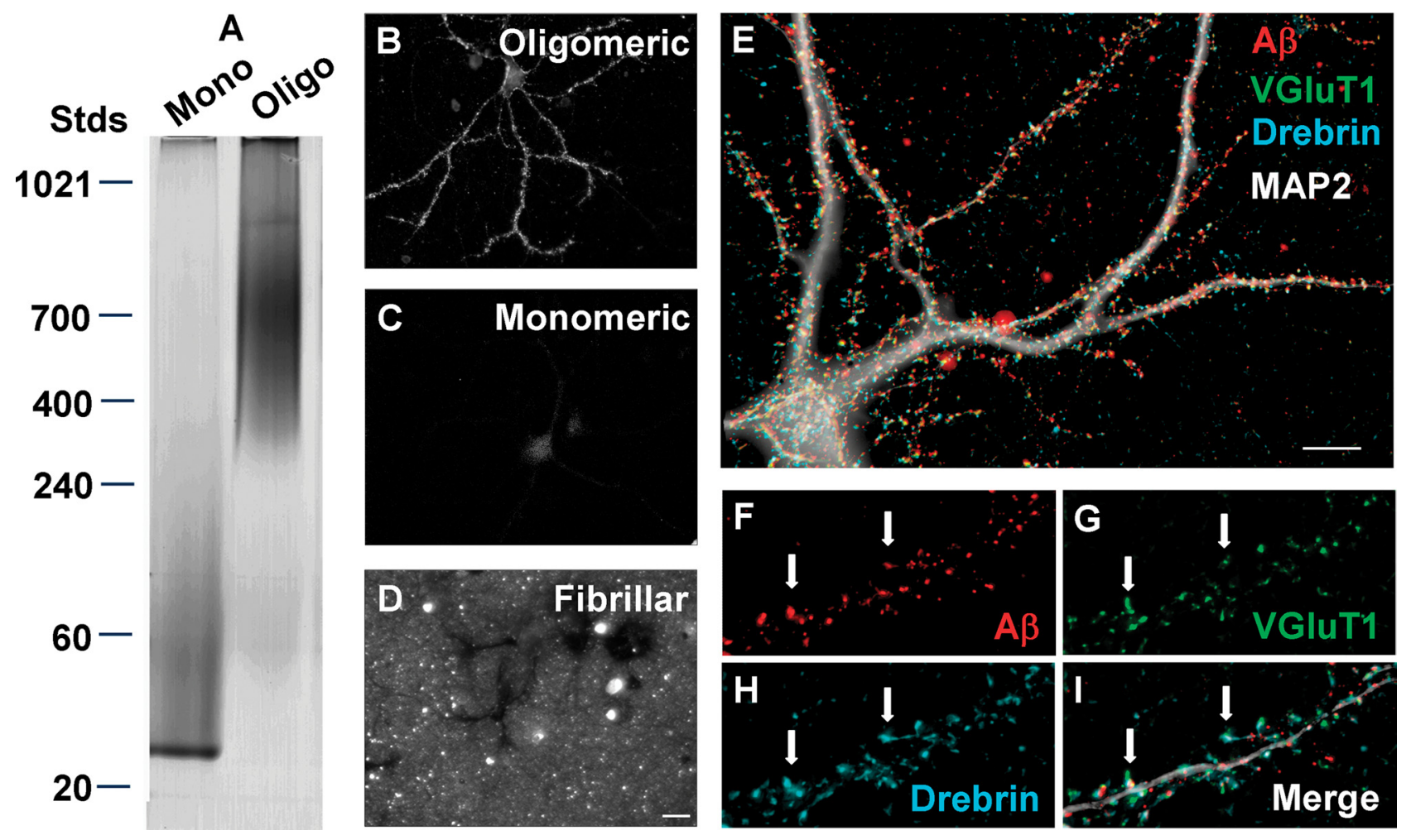

Figure 1. Soluble $A \beta$ species bind to excitatory synapses on hippocampal neurons. $A$, Electrophoretic analysis of freshly prepared (monomeric, Mono) or aged (oligomeric, Oligo) soluble $A \beta$ preparations (see Materials and Methods). $A \beta$ peptides were separated on a Tris-HCl polyacrylamide gel under native, nonreducing conditions and analyzed by silver stain. $B-I$, Oligomeric $A \beta$ species, but not monomeric or fibrillar, are targeted to excitatory synapses. Differentiated hippocampal neurons treated with $500 \mathrm{~nm}$ soluble (monomeric or oligomeric) and insoluble (fibrillar) $A \beta$ preparations and stained with polyclonal anti-A $\beta(\boldsymbol{B}-\boldsymbol{D})$ or fluorescently tagged $3 D 6 \mathrm{mAb}$ for $A \beta(\boldsymbol{E}, \boldsymbol{F}, \boldsymbol{I})$ and $\cos$ tained for MAP2 for dendrites $(\boldsymbol{E}, \boldsymbol{I})$, drebrin for spines $(\boldsymbol{E}, \boldsymbol{H}, \boldsymbol{I})$, and vesicular glutamate transporter 1 (VGluT1) for glutamatergic presynaptic terminals $(\boldsymbol{E}, \boldsymbol{G}, \boldsymbol{I})$. A $\beta$-positive clusters are found on soma and dendrites, almost exclusively restricted to excitatory synapses (arrows). Scale bar, $20 \mu \mathrm{m}$.

scribes several potential related species (e.g., oligomers, dimers, $A \beta^{\star} 56$, globulomers, $A \beta$-derived diffusible ligands, soluble protofibrils, etc.; Catalano et al., 2006; Walsh and Selkoe, 2007). The synaptotoxic species of soluble $A \beta$ is a debated subject in the field, though most groups appear to agree that it is larger than a monomer, soluble and likely constitutes an abnormally folded state of the peptide (Hepler et al., 2006).

We monitored the interaction of soluble $\mathrm{A} \beta$ with the surface of rat hippocampal neurons maintained for 3-4 weeks in vitro by quantitative immunocytochemical analysis. These neuronal-enriched cultures produce highly differentiated neurons with extensive synaptic input. The detection of $A \beta$ binding to neurons was performed with fluorescently tagged $3 \mathrm{D} 6$, a rabbit polyclonal anti-A $\beta$ antibody or, when using solutions from biotinylated $\mathrm{A} \beta_{1-42}$ peptide, fluorescent streptavidin (Shughrue et al., 2010). The pattern of distribution of $A \beta$ on the surface of neurons was indistinguishable among the different methods of detection. Consistent with previous reports (Zhao et al., 2010), we find that soluble, oligomeric $A \beta$ applied to hippocampal cultures selectively binds to the surface of a subpopulation of hippocampal neurons $(\sim 80 \%$ of neurons in the present studies), and distributes in a punctate pattern that is primarily restricted to excitatory synapses (Fig. 1 ), evidenced by the extensive colocalization between $A \beta$, the presynaptic glutamatergic marker VGluT1 and postsynaptic spine marker drebrin. The characteristic synaptic binding was absent when cultures were treated with $\mathrm{A} \beta$ solutions enriched in either low molecular weight assemblies or insoluble, fibril$\operatorname{lar} \mathrm{A} \beta$ (Fig. 1). Together, these results demonstrate that the
3D6 antibody can bind to soluble $\mathrm{A} \beta$ species that are selectively targeted to excitatory synapses.

The N-terminal mAb 3D6 blocks the binding of soluble A $\beta$ to hippocampal neurons

To assess the ability of 3D6 to neutralize soluble $A \beta$ binding we preincubated the antibody with soluble biotin- $A \beta$ before application to hippocampal neurons and detected binding using fluorescent-streptavidin. Furthermore, to evaluate the epitope specificity for protection against $\mathrm{A} \beta$ binding, we compared the 3D6 effects with those of monoclonal antibodies that bind to the C-terminal of $\mathrm{A} \beta_{1-42}, 21 \mathrm{~F} 12$ (amino acids 34-42) and 16C11 (amino acids 33-42), and to the $\mathrm{N}$-terminal of $\mathrm{A} \beta, 12 \mathrm{~A} 11$ (amino acids $3-7)$. We found that $3 \mathrm{D} 6\left(30 \mathrm{~min}, 37^{\circ} \mathrm{C}\right)$ effectively blocked the binding of soluble $\mathrm{A} \beta$ to synapses in a concentration-dependent manner (Fig. 2). The effect was detected at molar 3D6:A $\beta$ ratios as low as 1:100 $(p<0.001)$, and reached complete blockade of binding at equimolar ratios ( $p>0.05$ comparing to background values). In contrast, both C-terminal antibodies $21 \mathrm{~F} 12$ and $16 \mathrm{C} 11$ were ineffective in blocking $\mathrm{A} \beta$ binding $(p>0.05)$ while $12 \mathrm{~A} 11$ showed blocking equivalent to that of $3 \mathrm{D} 6$ at the ratios tested. We confirmed that the biotinylation of $\mathrm{A} \beta$ did not affect the ability of 3D6 or other antibodies to bind the $A \beta$ peptide by comparing results obtained from binding of nonbiotinylated $\mathrm{A} \beta$ preparations and detection with polyclonal antibody in a subset of experiments. The results of these studies suggest that the sequestration and the prevention of interaction of $\mathrm{A} \beta$ with neurons by $\mathrm{N}$-terminal antibodies like 3D6 are epitope specific (Fig. 2). 


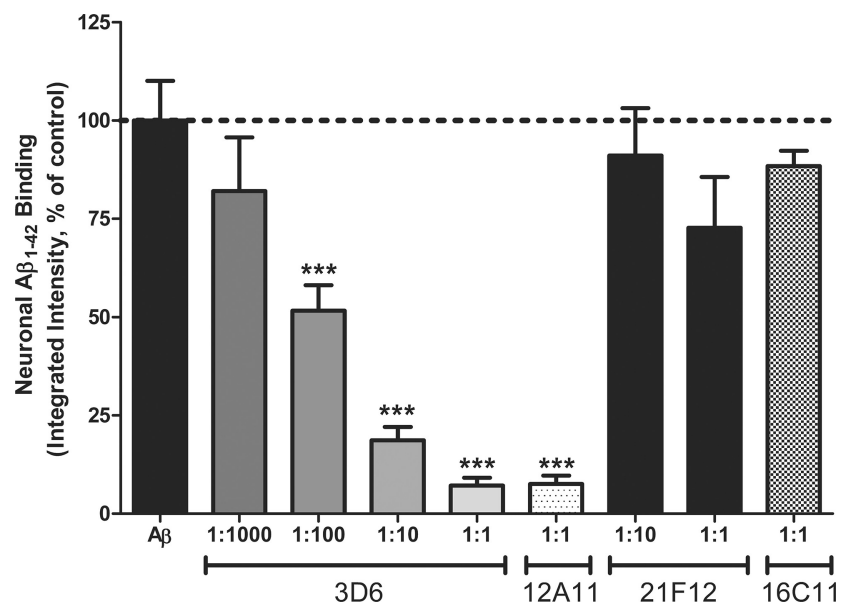

Figure 2. $3 D 6 \mathrm{mAb}$ blocks the binding of soluble $A \beta$ species to rat hippocampal neurons. Quantification of binding of soluble $A \beta$ to neurons in the presence of the N-terminal anti-A $\beta$ $\mathrm{mAbs} 3 \mathrm{D} 6$ and $12 \mathrm{~A} 11$ or C-terminal antibodies $21 \mathrm{~F} 12$ and $16 \mathrm{C} 11$. The data were normalized to control levels ( $A \beta$-only) and values represent the mean \pm SEMs of results from 14 to 53 optical fields ( $>2$ neurons per field), pooled from 4 to 6 independent experiments/cultures. Statistical differences were determined by ANOVA; ${ }^{* * *} p<0.001$ relative to the $A \beta$-only group.
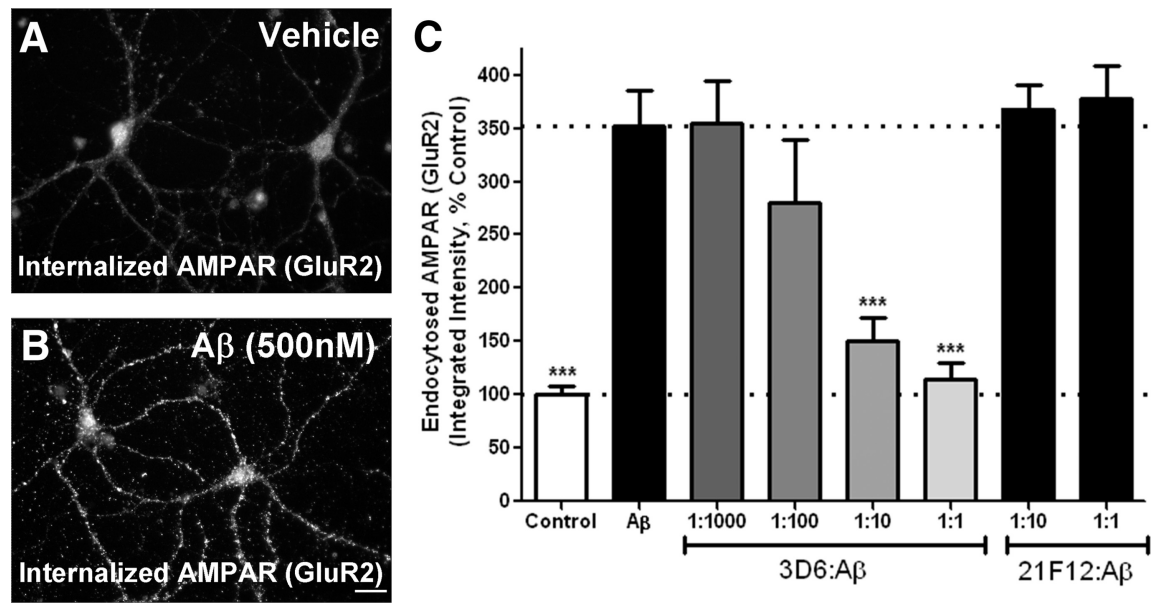

Figure 3. $3 D 6 \mathrm{mAb}$ blocks the $A \beta$-induced $A M P A$ receptor (AMPAR) endocytosis. $\boldsymbol{A}, \boldsymbol{B}$, Representative images of untreated cells showing low levels of AMPAR internalization under basal conditions $(\boldsymbol{A})$, whereas cells treated with $A \beta(\boldsymbol{B})$ demonstrate significant staining for AMPARs internalized from the plasma membrane. $C$, Quantification of AMPAR internalization in neurons treated with soluble $A \beta$ in the presence of anti-A $\beta$ mAbs. 3D6, but not 21F12 shows concentration-dependent blockage of soluble $A \beta$-induced AMPAR internalization. The data were normalized to control levels (vehicle control) and values represent the mean \pm SEMs of results from 15 optical fields ( $>2$ neurons per field), pooled from 3 independent experiments/cultures. Statistical differences were determined by ANOVA; ${ }^{* *} p<0.001$ relative to the $A \beta$-only group. Scale bar, $10 \mu \mathrm{m}$.

The N-terminal mAb 3D6 blocks soluble A $\beta$-induced internalization of AMPA receptors and loss of dendritic spines

Once bound to neurons, soluble $A \beta$ assemblies engage signaling pathways resulting in the endocytosis of synaptic AMPA receptor (AMPAR) proteins (Hsieh et al., 2006; Zhao et al., 2010). The consequent impaired regulation of receptor trafficking may underlie synaptic impairment and loss induced by soluble A $\beta$. Since 3D6 treatment neutralizes soluble $\mathrm{A} \beta$ species and prevents their binding to synapses (see above), we hypothesized that such administration would similarly protect against downstream, $A \beta$ induced synaptic changes. To evaluate this possibility we performed two independent studies. First, we determined whether 3D6 was capable of inhibiting the $\mathrm{A} \beta$-induced internalization of AMPA receptors in rat hippocampal neurons.
We used a previously described technique (Carroll et al., 1999; Zhao et al., 2010) which involved staining surface AMPARs with an antibody to the AMPAR subunit GluR2. Following A $\beta$ treatment, surface-bound antibodies were stripped so that only internalized AMPARs were visualized (details in Materials and Methods). Treatment of cultures with $\mathrm{A} \beta$ (500 nM for $15 \mathrm{~min}$ ) caused significant internalization of AMPARs (Fig. $3 A, B)$. These effects were restricted to somatic and dendritic areas of most hippocampal neurons. 3D6 $\left(30 \mathrm{~min}, 37^{\circ} \mathrm{C}\right)$ blocked $\mathrm{A} \beta$ induced increases in receptor internalization in a concentrationdependent manner (Fig. 3C). The antibody 21F12 was ineffective in preventing this effect. The application of the antibodies alone to neurons did not cause significant changes in AMPAR endocytosis relative to that observed in untreated cells $(97.4 \pm 5.1 \%$ of untreated control, $n=3$ ). In a second set of studies, we examined the effects of 3D6 on $A \beta$-induced changes in dendritic spine structure. A 24 h treatment of hippocampal cultures with $500 \mathrm{~nm}$ soluble $\mathrm{A} \beta$ caused a significant decrease in spine density when compared with control untreated cultures (Fig. $4 A, B$ ). Preincubation of soluble $\mathrm{A} \beta$ solutions with $3 \mathrm{D} 6$ before addition to neurons prevented the loss of spines in a concentration-dependent manner (Fig. 4C). The protection against spine loss was not observed in 21F12-treated samples.

\section{The N-terminal anti-A $\beta$ mAb 3D6 \\ blocks soluble $\mathrm{A} \boldsymbol{\beta}$-induced tau hyperphosphorylation in rat hippocampal neurons}

We next performed an investigation of the effects of 3D6 against soluble $\mathrm{A} \beta$ induced tau hyperphosphorylation in hippocampal neurons. We specifically evaluated phosphorylation of the tau protein at the Ser ${ }^{202}$ and $\mathrm{Thr}^{205}$ sites using the AT8 antibody, which has been used to detect hyperphosphorylated tau in CSF from AD patients. Consistent with previous reports (De Felice et al., 2008) we observed that $1 \mu \mathrm{m}$ soluble $\mathrm{A} \beta$ produced an increase in the immunofluorescence associated with phosphorylation of tau protein ( $\mathrm{p}$-Tau) over the period of 8 h (Fig. $5 A, B$ ). Preincubation of $\mathrm{A} \beta$ with $3 \mathrm{D} 6$ completely blocked the $\mathrm{A} \beta$-induced $\mathrm{p}$-Tau in a concentrationdependent manner, while the 21F12 antibody had no significant effect (Fig. 5C).

\section{The $\mathrm{N}$-terminal anti-A $\beta \mathrm{mAb} 3 \mathrm{D} 6$ acutely reverses $\mathrm{CFC}$} deficit in Tg2576 mice

Transgenic mice that overexpress the Swedish mutation of human amyloid precursor protein (hAPPswe; Tg2576) exhibit agedependent memory deficits in a Pavlovian fear-conditioning paradigm, the contextual fear conditioning (CFC) behavioral model. Deficits in CFC precede plaque deposition in the Tg2576 mouse model and can be acutely reversed by inhibitors of $A \beta$ production (Comery et al., 2005), suggesting that soluble $A \beta$ is primarily responsible for the observed deficits. To determine whether $3 \mathrm{D} 6$ targets and neutralizes soluble $\mathrm{A} \beta$ species in vivo, we examined CFC in Tg2576 mice following passive immunization. As shown in Figure 6, CFC is impaired in Tg2576 mice relative to 

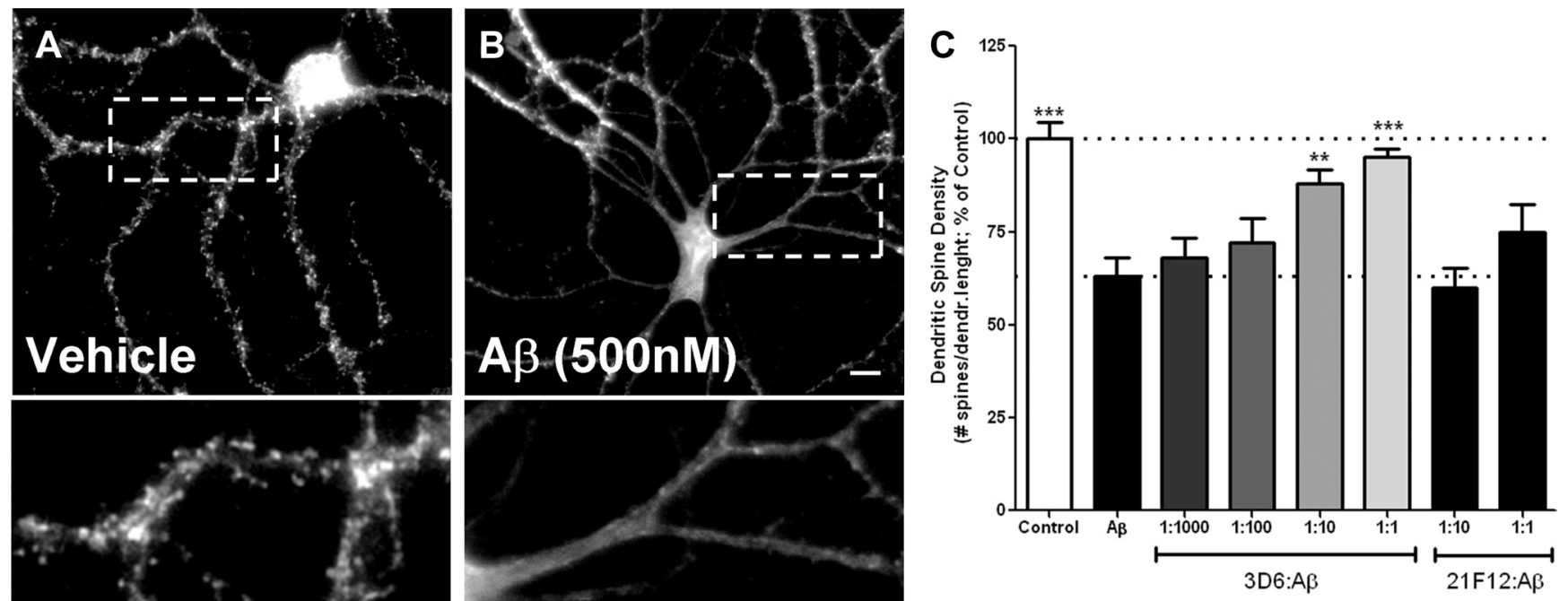

Figure 4. $3 D 6 \mathrm{mAb}$ blocks the $A \beta$-induced loss of dendritic spines. $A, B$, Representative images showing soluble $A \beta$-induced $(500 \mathrm{~nm}, 24 \mathrm{~h})$ spine loss in hippocampal neurons, visualized by spinophilin immunostaining. C, Quantification of spine density in neurons treated with soluble $A \beta$ in the presence of anti-A $\beta$ mAbs. 3D6, but not $21 F 12$, shows a concentration-dependent blockage of the soluble $A \beta$-induced loss of spine. The data were normalized to control levels (vehicle control) and values represent the mean \pm SEMs of results from 15 to 20 optical fields ( $>2$ neurons per field), pooled from 3 independent experiments/cultures. Statistical differences were determined by ANOVA; ${ }^{* *} p<0.001{ }^{* *} p<0.01$ relative to the A $\beta$-only group. Scale bar, $10 \mu \mathrm{m}$.

wild-type mice. As with other N-terminal anti-A $\beta$ mAbs (Basi et al., 2010) administration of 3D6 $24 \mathrm{~h}$ before the training session resulted in complete reversal of the behavioral deficit $(p>0.05$, comparing to wild-type; Fig. $6 A$ ). The antibody $21 \mathrm{~F} 12$, on the other hand, was ineffective in this paradigm (Fig. 6B).

\section{The N-terminal anti-A $\beta$ mAb 3D6} prevents synaptic loss in PDAPP mice We next investigated whether the protective properties of 3D6 against soluble $\mathrm{A} \beta$ induced changes in synaptic integrity in vitro would also be observed in vivo following chronic administration. PDAPP mice were immunized with systemic administration of either 3D6 or 21F12 for 6 months (3 mg/kg; weekly intraperitoneal injections) and the synaptophysin levels were quantified by immunofluorescence as previously described (Buttini et al., 2005). Consistent with the in vitro data, immunization with 3D6, but not 21F12, prevented the synaptic loss in PDAPP mice (Fig. 7). Interestingly, postmortem immunohistochemical analysis of PDAPP brains immunized with 3D6 did not reveal targeting of antibodies to synapses, consistent with the hypothesis that 3D6 may bind and neutralize soluble, synaptotoxic A $\beta$ species, preventing their binding to synaptic sites.

\section{Discussion}

The $\mathrm{A} \beta$ cascade is hypothesized to play a critical role in Alzheimer's disease (Hardy and Selkoe, 2002). While the A $\beta$ hypothesis was initially described based on the appearance of insoluble forms of $\mathrm{A} \beta$ found in the brains of $\mathrm{AD}$ patients, as well as the findings that missense mutations in both APP and presenilins cause rare familial forms of the disease, it has undergone iterative changes to accommodate the growing evidence that soluble ag-
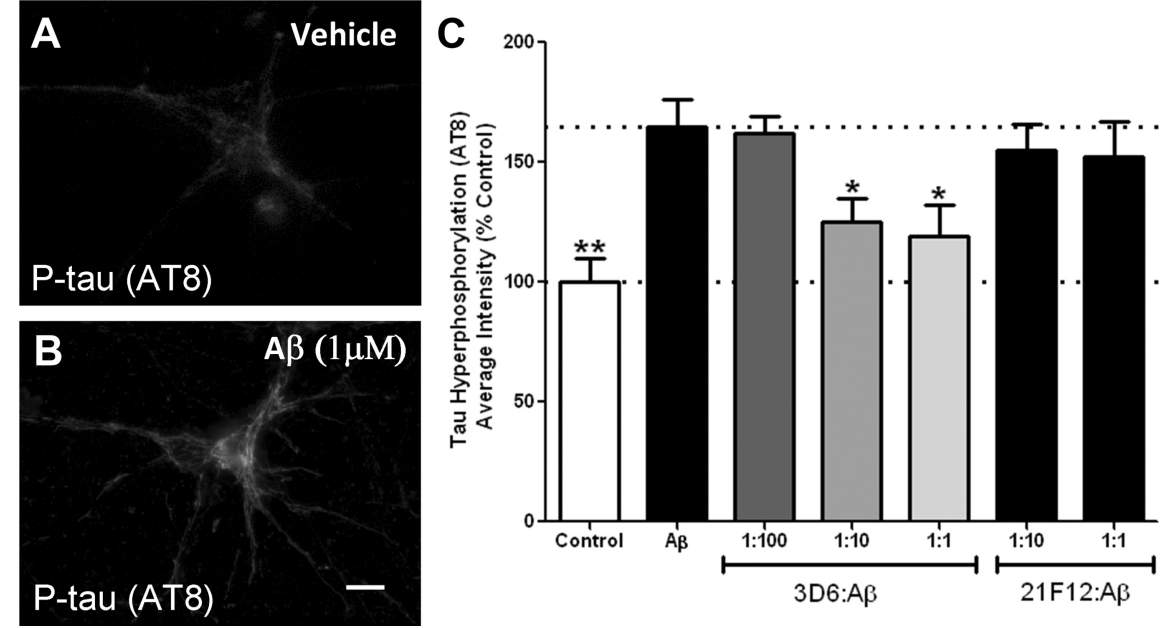

Figure 5. $3 \mathrm{D} 6 \mathrm{mAb}$ blocks the $A \beta$-induced tau hyperphosphorylation. $A, B$, Representative images showing soluble $A \beta$-induced (1 $\mu \mathrm{M}, 8 \mathrm{~h}$ ) tau hyperphosphorylation, visualized by staining with AT8 antibody. C, Quantification of tau hyperphosphorylation in neurons treated with soluble $A \beta$ in the presence of anti-A $\beta$ mAbs. $3 D 6$, but not $21 F 12$, shows a concentration-dependent blockage of the soluble fields ( $>2$ neurons per field), pooled from 5 independent experiments/cultures. Statistical differences were determined by ANOVA; ${ }^{* *} p<$ $0.01,{ }^{*} p<0.05$ relative to the $A \beta$-only group. Scale bar, $10 \mu \mathrm{m}$.

gregated forms of $\mathrm{A} \beta$ also play an important role in the disease process. Consistent with this hypothesis, several putative anti-A $\beta$ therapeutics have been forwarded into clinical trials. Among these approaches, a number of anti-A $\beta$ antibodies are currently under clinical evaluation for the treatment of mild to moderate AD. Since these various antibodies have been designed to target different epitopes on the $\mathrm{A} \beta$ peptide, it is important to understand their ability to interact with both soluble and insoluble forms of $\mathrm{A} \beta$. For example, while the mid-region-directed antibody 266 (a murine mAb with similar characteristics to solanezumab) is believed to interact with soluble forms of $A \beta$, it appears to be less effective in impacting insoluble forms of $\mathrm{A} \beta$ (Bard et al., 2003; Schroeter et al., 2008; Seubert et al., 2008). By contrast, N-terminal-directed antibodies such as 3D6 and 10D5 are effective in clearing $\mathrm{A} \beta$ plaque burden and vascular $\mathrm{A} \beta$ depo- 

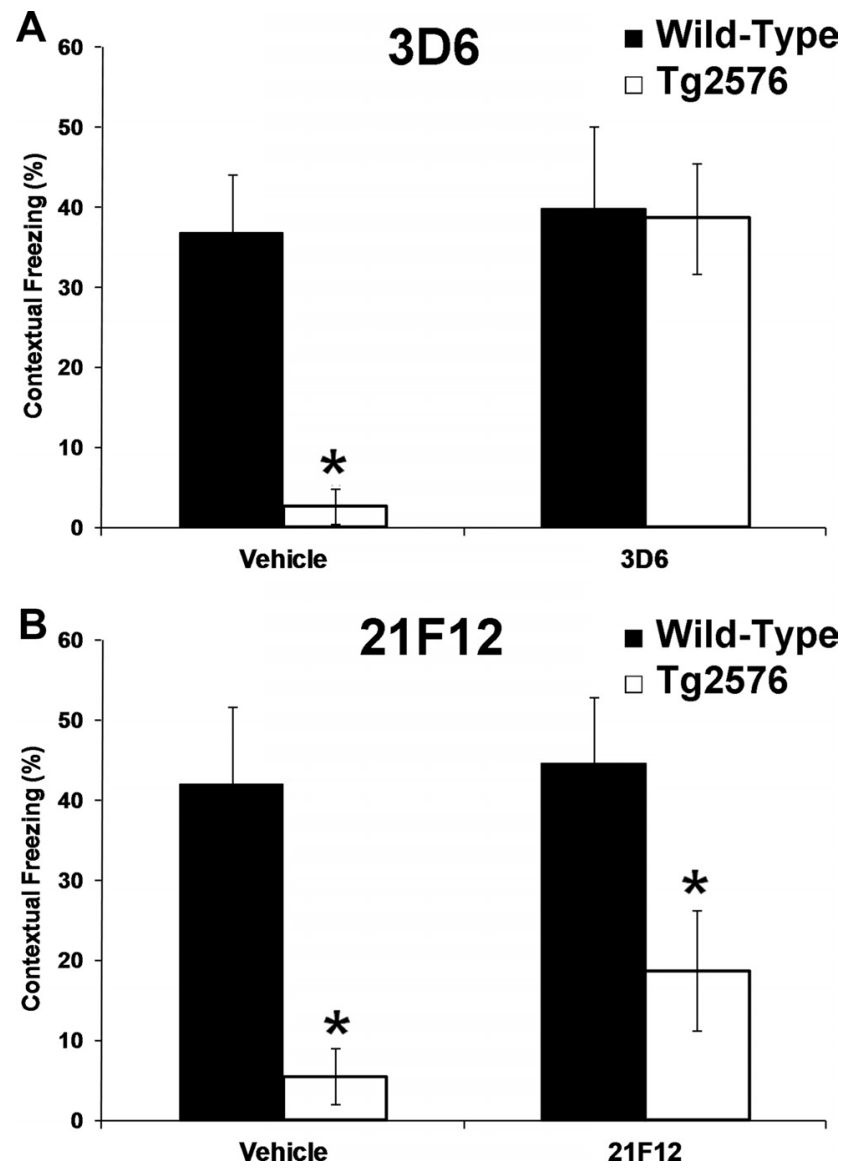

Figure 6. Passive immunization with $3 \mathrm{D} 6 \mathrm{mAb}$ acutely reverses the $A \beta$-related behavioral deficits in Tg2576 mouse. Effects of passive immunotherapy with 3D6 and 21F12 (both 30 $\mathrm{mg} / \mathrm{kg}$ ) $24 \mathrm{~h}$ before training. A, 3D6 restores the freezing behavior of Tg2576 to the levels exhibited by vehicle-treated wild-type. $\boldsymbol{B}, 21 F 12$ shows no significant effects. Neither $3 D 6$ nor 21F12 affect the freezing behavior in wild-type animals. The values represent the mean \pm SEMs of results from $n=8-12$ animals per genotype per treatment. Statistical differences were determined by ANOVA; ${ }^{*} p 0.05$ relative to wild-type.
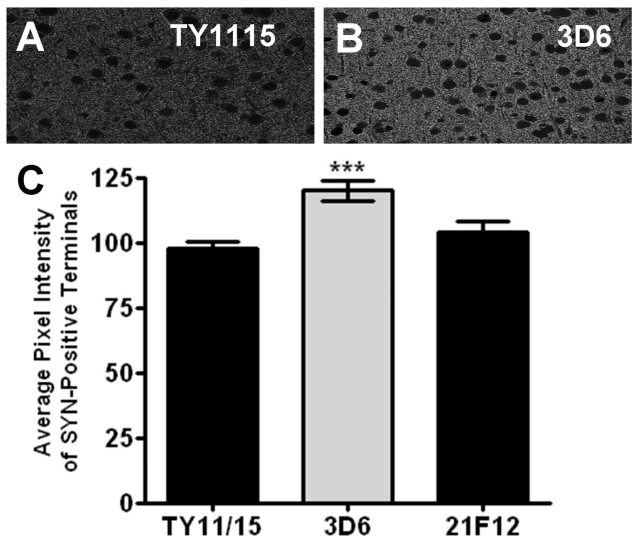

Figure 7. Passive $A \beta$ immunizations with $3 D 6$ prevented synaptophysin loss in the frontal neocortex of PDAPP mice. Effects of passive immunotherapy with anti-A $\beta \mathrm{mAbs}(3 \mathrm{mg} / \mathrm{kg}$ per week for 6 months) on neocortical synaptophysin levels. $\boldsymbol{A}, \boldsymbol{B}$, Representative images showing synaptophysin levels in control (TY11-15) and 3D6-treated animals. C, Significant improvements of synaptophysin levels over controls were found after passive immunization with 3D6, but not 21F12. Values represent the means \pm SEMs of results from $n=18-20$ animals per treatment group (4 optical fields per animal), Statistical differences were determined by ANOVA; ${ }^{* * *} p<0.001$ relative to the TY11-15 group. sition (Bard et al., 2000, 2003; Schroeter et al., 2008). While there is some evidence to suggest that $\mathrm{N}$-terminal antibodies also interact with and neutralize soluble forms of $\mathrm{A} \beta$ (Buttini et al., 2005; Shankar et al., 2008; Spires-Jones et al., 2009; Basi et al., 2010; Jin et al., 2011), the evidence to date has been relatively indirect and, as a result, confusion remains as to whether $\mathrm{N}$-terminal antibodies interact with soluble forms of A $\beta$ (Gandy, 2010). Monoclonal antibody $3 \mathrm{D} 6$ is the murine analog of the Phase $3 \mathrm{~N}$-terminaldirected anti- $\mathrm{A} \beta$ antibody bapineuzumab. As such, a full understanding of the ability of this antibody to interact with multiple forms of $A \beta$ may allow for a rational interpretation of any resultant clinical effects.

These present studies provide the first comprehensive comparison of N-terminally directed and C-terminally directed anti- $\mathrm{A} \beta$ antibodies on in vitro and in vivo endpoints sensitive to soluble $A \beta$. Our results demonstrate that 3D6 interacts with and neutralizes the binding of $A \beta$ to neurons and thereby prevents the soluble $A \beta$-induced aberrant trafficking of AMPA receptors, synaptic spine downregulation and tau phosphorylation. The effects of 3D6 were potent, with disruption of soluble $\mathrm{A} \beta$ binding noted at antibody $/ \mathrm{A} \beta$ ratios as low as 1:100. These results are consistent with those previously reported by Shankar et al. (2008), where 3D6 reversed impairments in LTP induced by AD brain homogenates, and by Spires-Jones et al. (2009), where 3D6 acutely (1 h) rescued the disruption in dendritic spine plasticity observed in PDAPP mouse brains. In both the Shankar and Spires-Jones studies, it was assumed that soluble $A \beta$ was the relevant component promoting changes in synaptic function and form. The current studies demonstrating a direct interaction of 3D6 and soluble $A \beta$ on synaptic endpoints support this interpretation. The changes in AT8-p-Tau are consistent with reports of decreased total tau and $\mathrm{p}$-Tau in the CSF of patients treated with bapineuzumab (Blennow et al., 2010).

In an effort to understand whether the effects observed in vitro were relevant to in vivo endpoints, we evaluated the effect of 3D6 and 21F12 treatment on two in vivo pharmacodynamic endpoints sensitive to soluble $A \beta$. The first evaluation used the CFC test. Tg2576 hAPP-expressing mice are deficient in CFC, an effect that is evident before plaque formation and sensitive to reductions in $\mathrm{A} \beta$ production (Comery et al., 2005). 3D6, but not $21 \mathrm{~F} 12$, treatment completely reversed the deficits in Tg2576 mice following a single administration. A second in vivo evaluation examined the quantitation of synapses using synaptophysin immunoreactivity in the PDAPP mouse model. Since the loss of synaptophysin immunoreactivity in PDAPP mice found throughout the brain is not restricted to areas proximal to plaque, and does not correlate with amyloid plaque load in both immunized and nonimmunized animals (Buttini et al., 2005), these deficits are believed to be caused by increased soluble $\mathrm{A} \beta$. Consistent with a prior report (Buttini et al., 2005), repeated administration of 3D6, but not 21F12, demonstrated a protective effect on this endpoint. These in vivo studies collectively suggest that the effects observed in the present experiments in vitro are also relevant in vivo.

To understand the degree to which any putative anti-A $\beta$ clinical therapeutic tests the $\mathrm{A} \beta$ hypothesis of $\mathrm{AD}$, it is critical to fully understand the interaction of these antibodies with all forms of $\mathrm{A} \beta$ including both soluble and insoluble forms of the peptide. In this regard, the precise reactivity of a specific antibody to a rather small peptide- $A \beta$, appears to have significantly different biological effects in preclinical and potentially clinical settings. 


\section{References}

Bard F, Cannon C, Barbour R, Burke RL, Games D, Grajeda H, Guido T, Hu K, Huang J, Johnson-Wood K, Khan K, Kholodenko D, Lee M, Lieberburg I, Motter R, Nguyen M, Soriano F, Vasquez N, Weiss K, Welch B, et al. (2000) Peripherally administered antibodies against amyloid betapeptide enter the central nervous system and reduce pathology in a mouse model of Alzheimer disease. Nat Med 6:916-919.

Bard F, Barbour R, Cannon C, Carretto R, Fox M, Games D, Guido T, Hoenow K, Hu K, Johnson-Wood K, Khan K, Kholodenko D, Lee C, Lee M, Motter R, Nguyen M, Reed A, Schenk D, Tang P, Vasquez N, et al. (2003) Epitope and isotype specificities of antibodies to beta-amyloid peptide for protection against Alzheimer's disease-like neuropathology. Proc Natl Acad Sci U S A 100:2023-2028.

Basi GS, Feinberg H, Oshidari F, Anderson J, Barbour R, Baker J, Comery TA, Diep L, Gill D, Johnson-Wood K, Goel A, Grantcharova K, Lee M, Li J, Partridge A, Griswold-Prenner I, Piot N, Walker D, Widom A, Pangalos MN, et al. (2010) Structural correlates of antibodies associated with acute reversal of amyloid beta-related behavioral deficits in a mouse model of Alzheimer disease. J Biol Chem 285:3417-3427.

Black RS, Sperling RA, Safirstein B, Motter RN, Pallay A, Nichols A, Grundman M (2010) A single ascending dose study of bapineuzumab in patients with Alzheimer disease. Alzheimer Dis Assoc Disord 24:198-203.

Blennow K, Zetterberg H, Wei J, Liu E, Black R, Grundman M (2010) Immunotherapy with bapineuzumab lowers CSF tau protein levels in patients with Alzheimer's disease. In: Alzheimer's Association International Conference on Alzheimer's Disease 2010, Honolulu, HI, July.

Buttini M, Masliah E, Barbour R, Grajeda H, Motter R, Johnson-Wood K, Khan K, Seubert P, Freedman S, Schenk D, Games D (2005) Betaamyloid immunotherapy prevents synaptic degeneration in a mouse model of Alzheimer's disease. J Neurosci 25:9096-9101.

Carroll RC, Beattie EC, Xia H, Lüscher C, Altschuler Y, Nicoll RA, Malenka RC, von Zastrow M (1999) Dynamin-dependent endocytosis of ionotropic glutamate receptors. Proc Natl Acad Sci U S A 96:14112-14117.

Catalano SM, Dodson EC, Henze DA, Joyce JG, Krafft GA, Kinney GG (2006) The role of amyloid-beta derived diffusible ligands (ADDLs) in Alzheimer's disease. Curr Top Med Chem 6:597-608.

Comery TA, Martone RL, Aschmies S, Atchison KP, Diamantidis G, Gong X, Zhou H, Kreft AF, Pangalos MN, Sonnenberg-Reines J, Jacobsen JS, Marquis KL (2005) Acute gamma-secretase inhibition improves contextual fear conditioning in the $\operatorname{Tg} 2576$ mouse model of Alzheimer's disease. J Neurosci 25:8898-8902.

De Felice FG, Wu D, Lambert MP, Fernandez SJ, Velasco PT, Lacor PN, Bigio EH, Jerecic J, Acton PJ, Shughrue PJ, Chen-Dodson E, Kinney GG, Klein WL (2008) Alzheimer's disease-type neuronal tau hyperphosphorylation induced by A beta oligomers. Neurobiol Aging 29:1334-1347.

Gandy S (2010) Testing the amyloid hypothesis of Alzheimer's disease in vivo. Lancet Neurol 9:333-335.

Gilman S, Koller M, Black RS, Jenkins L, Griffith SG, Fox NC, Eisner L, Kirby L, Rovira MB, Forette F, Orgogozo JM (2005) Clinical effects of Abeta immunization (AN1792) in patients with $\mathrm{AD}$ in an interrupted trial. Neurology 64:1553-1562.

Hardy J, Selkoe DJ (2002) The amyloid hypothesis of Alzheimer's disease: progress and problems on the road to therapeutics. Science 297:353-356.

Hepler RW, Grimm KM, Nahas DD, Breese R, Dodson EC, Acton P, Keller PM, Yeager M, Wang H, Shughrue P, Kinney G, Joyce JG (2006) Solution state characterization of amyloid beta-derived diffusible ligands. Biochemistry 45:15157-15167.
Hsieh H, Boehm J, Sato C, Iwatsubo T, Tomita T, Sisodia S, Malinow R (2006) AMPAR removal underlies Abeta-induced synaptic depression and dendritic spine loss. Neuron 52:831-843.

Jin M, Shepardson N, Yang T, Chen G, Walsh D, Selkoe DJ (2011) Soluble amyloid beta-protein dimers isolated from Alzheimer cortex directly induce Tau hyperphosphorylation and neuritic degeneration. Proc Natl Acad Sci U S A 108:5819-5824.

Lacor PN, Buniel MC, Chang L, Fernandez SJ, Gong Y, Viola KL, Lambert MP, Velasco PT, Bigio EH, Finch CE, Krafft GA, Klein WL (2004) Synaptic targeting by Alzheimer's-related amyloid beta oligomers. J Neurosci 24:10191-10200.

Lambert MP, Viola KL, Chromy BA, Chang L, Morgan TE, Yu J, Venton DL, Krafft GA, Finch CE, Klein WL (2001) Vaccination with soluble Abeta oligomers generates toxicity-neutralizing antibodies. J Neurochem 79:595-605.

Nicoll JA, Wilkinson D, Holmes C, Steart P, Markham H, Weller RO (2003) Neuropathology of human Alzheimer disease after immunization with amyloid-beta peptide: a case report. Nat Med 9:448-452.

Orgogozo JM, Gilman S, Dartigues JF, Laurent B, Puel M, Kirby LC, Jouanny P, Dubois B, Eisner L, Flitman S, Michel BF, Boada M, Frank A, Hock C (2003) Subacute meningoencephalitis in a subset of patients with $A D$ after Abeta42 immunization. Neurology 61:46-54.

Panza F, Frisardi V, Imbimbo BP, Seripa D, Paris F, Santamato A, D'Onofrio G, Logroscino G, Pilotto A, Solfrizzi V (2011) Anti-beta-amyloid immunotherapy for Alzheimer's disease: focus on bapineuzumab. Curr Alzheimer Res.

Schenk D (2002) Amyloid-beta immunotherapy for Alzheimer's disease: the end of the beginning. Nat Rev Neurosci 3:824-828.

Schroeter S, Khan K, Barbour R, Doan M, Chen M, Guido T, Gill D, Basi G, Schenk D, Seubert P, Games D (2008) Immunotherapy reduces vascular amyloid-beta in PDAPP mice. J Neurosci 28:6787-6793.

Seubert P, Barbour R, Khan K, Motter R, Tang P, Kholodenko D, Kling K, Schenk D, Johnson-Wood K, Schroeter S, Gill D, Jacobsen JS, Pangalos M, Basi G, Games D (2008) Antibody capture of soluble Abeta does not reduce cortical Abeta amyloidosis in the PDAPP mouse. Neurodegener Dis 5:65-71.

Shankar GM, Li S, Mehta TH, Garcia-Munoz A, Shepardson NE, Smith I, Brett FM, Farrell MA, Rowan MJ, Lemere CA, Regan CM, Walsh DM, Sabatini BL, Selkoe DJ (2008) Amyloid-beta protein dimers isolated directly from Alzheimer's brains impair synaptic plasticity and memory. Nat Med 14:837-842.

Shughrue PJ, Acton PJ, Breese RS, Zhao WQ, Chen-Dodson E, Hepler RW, Wolfe AL, Matthews M, Heidecker GJ, Joyce JG, Villarreal SA, Kinney GG (2010) Anti-ADDL antibodies differentially block oligomer binding to hippocampal neurons. Neurobiol Aging 31:189-202.

Spires-Jones TL, Mielke ML, Rozkalne A, Meyer-Luehmann M, de Calignon A, Bacskai BJ, Schenk D, Hyman BT (2009) Passive immunotherapy rapidly increases structural plasticity in a mouse model of Alzheimer disease. Neurobiol Dis 33:213-220.

Walsh DM, Selkoe DJ (2007) A beta oligomers - a decade of discovery. J Neurochem 101:1172-1184.

Zhao WQ, Santini F, Breese R, Ross D, Zhang XD, Stone DJ, Ferrer M, Townsend M, Wolfe AL, Seager MA, Kinney GG, Shughrue PJ, Ray WJ (2010) Inhibition of calcineurin-mediated endocytosis and alphaamino-3-hydroxy-5-methyl-4-isoxazolepropionic acid (AMPA) receptors prevents amyloid beta oligomer-induced synaptic disruption. J Biol Chem 285:7619-7632. 